\title{
PENGARUH KOMPRES HANGAT TERHADAP TINGKAT NYERI PERSALINAN KALA I PADA IBU BERSALIN DI BPM RABIAH PALEMBANG TAHUN 2017
}

\author{
Meta Rosdiana ${ }^{1}$, Asih Fatriansari ${ }^{2}$, Popi Vitaloka Oktavaini Nasaru ${ }^{3}$ \\ Program Studi Diploma III Kebidanan STIK Siti Khadijah Palembang \\ Jl. Demang Lebar Daun Lorok Pakjo Komplek RSI Siti Khadijah Palembang 30137 \\ Email : rosdiana.meta76@gmail.com
}

\begin{abstract}
Abstrak
Upaya dalam mengatasi nyeri persalinan ada dua metode yaitu secara medis dan non medis. Tindakan non medis salah satunya adalah pemberian kompres hangat yang diberikan didaerah punggung bawah. Penelitian ini didasarkan dari hasil wawancara yang dilakukan di BPM Rabiah Palembang bahwa metode yang diunakan untuk mengatasi nyeri pada ibu bersalin adalah pijat punggung dan pemberian dukungan emosional, sedangakan pemberian kompres hangat belum pernah diterapkan. Penelitian ini bertujuan untuk mengetahui pengaruh kompres hangat terhadap tingkat nyeri persalinan kala I pada ibu bersalin di BPM Rabiah Palembang tahun 2017. Desain penelitian ini menggunakan metode pre eksperimental dengan pendekatan pretest dan postest. Sampel penelitian ini berjumlah $10 \mathrm{ibu}$ bersalin normal di BPM Rabiah Palembang tahun 2017. Dalam penelitian ini tingkat nyeri persalinan sebelum intervensi tertinggi pada kelompok nyeri sedang sebesar 5 responden. Tingkat nyeri persalinan sesudah intervensi tertinggi berada pada kelompok nyeri ringan sebanyak 6 responden. Hasil uji statistik wilcoxon signed rank test didaptkan nilai $p$ value adalah 0.003 maka dapat disimpulkan ada pengaruh kompres hangat terhadap tingkat nyeri persalinan di BPM Rabiah Palembang. Diharapkan penelitian ini dapat diterapkan di BPM Rabiah palembang agar dapat membantu mengatasi, mengurangi nyeri persalinan, dan memberikan rasa nyaman dan rileks pada ibu bersalin.
\end{abstract}

Kata kunci : kompres hangat, tingkat nyeri persalinan

\section{THE INFLUENCE OF WARM COMPRESS TO THE LEVEL OF MATERNITY PAIN ON THE FIRST STAGE AT BPM RABIAH PALEMBANG IN 2017}

\begin{abstract}
There were two methods to decrease the maternity pain : medical and non-medical. Nonmedical action one of them is a warm compress given in the area of the lower bcak. This study is based on th results of interviews conducted at BPM Rabiah Palembang the the method used to overcome the pain in the maternal mother is back massage and emotional support, while the provision of warm compress has never been applied. This study aims to determaine the effect of warm compress on the level of maternity pain in the first stage of maternal womb in BPM Rabiah Palembang in 2017. This research design used pre experimental methode with pretest and posstest approach. The sample of this study were 10 normal maternity women in BPM Rabiah Palembang in 2017. In this study the level of maternity pain before the highest intervention in the group of moderate pain was 5 respondent. The level of maternity pain after intervention was highest in the mild pain group of 6 respondents. The result of statistical test of wilcoxon signed rank test was obtained $p$ value of 0.003 , it can be concluded that there is influence of warm compress on the level of maternity pain in the first stage of maternal womb in BPM Rabiah Palembang. It is expected that this research can be applied in BPM Rabiah Palembang in order to help overcome, reduce maternity pain, and give comfort and relax to mother of birth.
\end{abstract}

Keywords: Warm Compress, Maternity Pain 



\section{PENDAHULUAN}

Persalinan normal menurut WHO (World Health Organisation) adalah persalinan yang dimulai secara spontan, beresiko rendah pada awal persalinan dan tetap demikianselama proses persalinan,bayi lahir secara spontan dalam presentasi belakang kepala pada usia kehamilan 37-42 minggu lengkap dan setelah persalinan ibumaupun bayi berada dalam kondisi sehat (WHO, 2012). Menurut Manuaba (2010) dalam Rukiah, dkk (2014) Persalinan adalah proses pengeluaran hasil konsepsi (janin dan plasenta) yang telah cukup bulan atau dapat hidup diluar kandungan melalui jalan lahir atau melalui jalan lain, dengan bantuan atau dengan kekutan sendiri.

Menurut data dari Profil Kesehatan Indonesia tahun 2014, cakupan persalinan yag ditolong oleh tenaga kesehatan secara nasional pada tahun 2014 yaitu sebesar $88.86 \%$ dimana angka ini belum memenuhi target Renstra kementrian kesehatan tahun 2014 yakni sebesar 90\%. Namun, di beberapa Provinsi sudah mencapai target Renstra, yakni tiga diantara lain DI Yogyakarta $(99,96 \%)$, Jawa tengah $(99,17 \%)$, dan Bali $(97,66 \%)$.

Data cakupan persalinan yang ditolong oleh tenaga kesehatan pada tahun 2014 mencapai $91.72 \%$. Capaian cakupan pertolongan persalinan oleh tenaga kesehatan di Kabupaten/Kota berkisar antara $84.85 \%-98.07 \%$, dimana capaian tertinggi ada di Kab. OKU Selatan (98.07\%), kemudian diikuti oleh Kab. OKI (95.14\%), dan Kota Prabumulih (95.01\%). Sementara capaian terendah di Kab. Musi Rawas (85.45\%) dan Empat Lawang (84.85\%). (Profil Kesehatan Sumatera Selatan, 2014)

Pencapaian cakupan persalinan ditolong oleh tenaga kesehatan di Kota Palembang tahun 2015 sebesar 95.58\%. cakupan tertinggi di kecamatan ilir timur II dimana seluruh ibu bersalin di tolong oleh tenaga kesehatan (104.73\%), dan terendah $(82.59 \%)$ berada di kecamatan sematang borang (Profil Kesehatan Kota Palembang, 2015).

Secara fisiologi nyeri persalinan mulai timbul pada persalinan kala I fase laten dan fase aktif. Fase laten terjadi pembukaan sampai $3 \mathrm{~cm}$, bisa berlangsung selama 12 jam pada primigravida sedangkan pada multigravida selama 8 jam dan fase aktif berdasarkan kurve firedman, diperhitungkan pembukaan primigravida 1 $\mathrm{cm} / \mathrm{jam}$ dan pembukaan multigravida 2 $\mathrm{cm} /$ jam (Rukiah, dkk, 2014).

Mengingat dampak nyeri cukup signifikan bagi ibu dan bayi, maka harus ada upaya untuk menurunkan nyeri tersebut. Upaya tersebut adalah dengan tindakan medis dan non medis. Salah satu tindakan non medis untuk mengurangi rasa nyeri persalinan antara lain pemberian kompres hangat, tindakan tersebut adalah untuk distraksi yang dapat menghambat otot untuk mengeluarkan sensasi nyeri dan dapat meningkatkan kepuasan selama persalinan karena ibu dapat mengontrol perasaan dan kekuatannya (Indrawan, dkk, 2010 dkutip dalam Wahyuni, 2014).

Menurut Uliyah, dkk, 2006 dikutip dalam Ratnasari, 2015 Kompres panas atau dingin adalah salah satu metode nonfarmakologi dianggap sangat efektif dalam menurunkan kasus-kasus nyeri. Kompres panas adalah tindakan dengan memberikan kompres hangat yangbertujuan memenuhi kebutuhan rasa nyaman, mengurangi atau membebaskannyeri, mencegah terjadinya spasme otot, dan memberikan rasa hangat.

Pemberian kompres hangat pada daerah tubuh akan memberikan signal ke hipothalamus melalui spinal cord. Ketika reseptor yang peka terhadap panas dihipotalamus dirangsang, sistem efektor mengeluarkan signal yang memulai berkeringat dan perifer. Perubahan ukuran pembuluh darah akan memperlancar sirkulasi oksigenisasi mencegah terjadinya spasme otot, memberikan rasa hangat membuat otot tubuh lebih rileks, dan menurunkan rasa nyeri (Wahyuni, 2014).

Tahun 2014 jumlah persalinan spontan di BPM Rabiah Palembang 
berjumlah 178 orang dan tahun 2015 berjumlah 156 orang dan tahun 2016 berjumlah 155 orang, serta pada bulanJanuari sampai dengan bulan April 2017 sebanyak 40 orang.

Hasil studi pendahuluan melalui wawancara yang dilakukan pada bidan di BPM Rabiah Palembang mereka mengatakan tidak pernah melakukan Kompres hangatpada saat mengatasi nyeri persalinan Kala I. Mereka lebih cenderung menggunakan terapi massase punggung pasien dan mengatur posisi. Jadi metode untuk mengatasi nyeri persalinan kala I terapi non-farmakologi seperti pemberian kompres hangat belum pernah diterapkan.

Berdasarkan uraian diatas, maka penulis tertarik mengadakan peneltian tentang "Pengaruh Kompres Hangat terhadap Tingkat Nyeri Persalinan Kala I pada Ibu Bersalin di BPM Rabiah Palembang tahun 2017.

\section{METODE PENELITIAN}

Penelitian menggunakan desain eksperimental dengan pendekatan preeksperimental one group pretest-posttest. 2017.

Populasi dalam penelitian ini adalah semua ibu bersalin normal yang datang ke BPM Rabiah Palembang. Sampel yang diambil sebanyak 10 responden dengan teknik AccidentalSampling. Metode pengumpulan data menggunakan metode Wawancara dengan menggunakan lembar Check List.

Dilakukan di BPM Rabiah Palembang pada tanggal 22 Juni- 10 Juli 2017.

HASIL

\section{Sebelum Pemberian kompres hangat} Tabel 1

Distribusi FrekuensiPretest Responden Berdasarkan Tingkat Nyeri di BPM Rabiah Palembang Tahun 2017.

\begin{tabular}{llc}
\hline $\begin{array}{c}\text { Tingkat Nyeri } \\
\text { Persalinan } \\
\text { Pretest }\end{array}$ & jumlah & $\%$ \\
\hline $\begin{array}{c}\text { Tidak Nyeri (0) } \\
\text { Nyeri Ringan (1- } \\
\text { 3) }\end{array}$ & 1 & 0 \\
$\begin{array}{c}\text { Nyeri Sedang (4- } \\
\text { 6) }\end{array}$ & 5 & 50 \\
$\begin{array}{c}\text { Nyeri Berat (7- } \\
\text { 9) }\end{array}$ & 4 & 40 \\
$\begin{array}{c}\text { Nyeri Sangat } \\
\text { Berat (10) }\end{array}$ & 0 & 0 \\
\hline $\begin{array}{c}\text { Jumlah } \\
\text { Berdasarkan } \\
\text { bahwa tabel } \\
\text { tingkat }\end{array}$ & $\begin{array}{c}\text { diatas } \\
\text { nyeri }\end{array}$ \\
menunjukan \\
persalinan sebelum kompres hangat yang \\
tertinggi berada pada kelompok \\
nedang sebesar 5 responden (50\%).
\end{tabular}

\section{Sesudah Pemberian kompres hangat} Tabel 2

Distribusi FrekuensiPosttest Responden Berdasarkan Tingkat Nyeri di BPM Rabiah Palembang Tahun 2017.

\begin{tabular}{ccc}
\hline $\begin{array}{c}\text { Tingkat Nyeri } \\
\text { Persalinan } \\
\text { Posttest }\end{array}$ & Jumlah & $\%$ \\
\hline $\begin{array}{c}\text { Tidak Nyeri (0) } \\
\text { Nyeri Ringan } \\
(1-3)\end{array}$ & 0 & 0 \\
$\begin{array}{c}\text { Nyeri Sedang } \\
\quad(4-6)\end{array}$ & 6 & 60 \\
$\begin{array}{c}\text { Nyeri Berat (7- } \\
\text { 9) }\end{array}$ & 0 & 0 \\
$\begin{array}{c}\text { Nyeri Sangat } \\
\text { Berat (10) }\end{array}$ & 0 & 0 \\
\hline Jumlah & 10 & 100 \\
\hline
\end{tabular}

Berdasarkan tabel diatas menunjukan bahwa tingkat nyeri persalinan sesudah kompres hangat yang tertinggi berada pada kelompok nyeri ringan sebanyak 6 responden $(60 \%)$. 
3. Pengaruh kompres hangat terhadap tingkat nyeri persalinan Tabel. 3

\section{Hasil uji statistikPengaruh Kompres Hangat Terhadap Tingkat Nyeri Persalinan di BPM Rabiah Palembang Tahun 2017.}

\begin{tabular}{|c|c|c|}
\hline & $\begin{array}{c}\text { Median } \\
\text { (minimum- } \\
\text { maksimum }\end{array}$ & Nilai $\boldsymbol{p}$ \\
\hline $\begin{array}{c}\text { Sebelum } \\
\text { Intervensi }\end{array}$ & $3(2-4)$ & $\mathbf{0 , 0 0 3}$ \\
\hline $\begin{array}{c}\text { Sesudah } \\
\text { Intervensi }\end{array}$ & $2(2-3)$ & \\
\hline
\end{tabular}

Berdasarkan tabel diatas didapatkan bahwa $p$ value sebesar 0.003 dimana kurang dari batas kemaknaan $\alpha=$ 0.05, maka dapat disimpulkan ada perbedaan yang signifikan antara tingkat nyeri persalinan sebelum dan sesudah kompres hangat.

\section{PEMBAHASAN}

Distribusi frekuensi sebelum intervensi, responden dengan kategori nyeri ringan 1 responden $(10 \%)$, kategori nyeri sedang sejumlah 5 responden $(50 \%)$, dan kategori nyeri berat sejumlah 4 responden $(40 \%)$.

Distribusi frekuensi sesudah intervensi, responden dengan kategori nyeri ringan 6 responden $(60 \%)$ dan kategori nyeri sedang sejumlah 4 responden (40\%).

Berdasakan hasil uji statistik wilcoxon signed rank test didapatkan besrnya nilai $\mathrm{Z}$ hitung sebesar $-3.000^{\mathrm{a}}$ dengan $p$ value $=0.003$ dimana kurang dari batas kemaknaan $\alpha=0.05$, sehingga keputusan hipotesis $\mathrm{Ha}$ diterima yang berarti ada pengaruh kompres hangat terhdap tingkat nyri persalinan kala I pada ibu bersalin di BPM Rabiah Palembang Tahun 2017.

Penelitian ini didukung oleh teori yang dikemukakan oleh Simkin dan Ancheta, 2005. Kompres hangat meningkatkan suhu kulit lokal, sirkulasi dan metabolisme jaringan, kompres hangat lokal atau selimut hangat akan menenangkan wanita terhadap jenis massase yang dihentakkan yang tidak dapat ditoleransi wanita saat kulitnya sensitive atau sakit berkaitan dengan respons melawan atau menghindar. Suatu studi kecil tentang kompres hangat (botol air hangat) yang diletakkan di fundus menemukan bahwa tindakan ini akan meningkatkan aktivitas rahim.

Penelitian ini sejalan dengan hasil penelitian yang dilakukan oleh Ratnasari, 2015 dengan judul Pengaruh kompres hangat terhadap penurunan nyeri persalinan kala I di BPM Wilkaden Imogri Bantul Yogyakarta. Berdsarkan hasil penelitian dari 12 Responden. Tingkat nyeri sebelum dilakukan kompes hangat adalah sebagian besar berada pada nyeri sedang sebesar 7 responden $(58.3 \%)$ dan nyeri berat sebanyak 5 responden $(41.7 \%)$. Tingkat nyeri sesudah dilakukan kompres hangat adalah sebagian besar ibu berada pada nyeri sedang 7 responden $(33.3 \%)$, nyeri ringan sebanyak 4 responden $(58.3 \%)$ dan nyeri berat sebanyak 1 responden $(8.3 \%)$. hasil analisa nilai $\mathrm{Z}$ hitung sebesar -2.992 dengan signifikan $0.003, p$ value $=0.003<\alpha=0.05$, artinya terdapat perbedaan signifikn tingkat nyeri sebelm dan sesudah diberi kompres hangat.

Berdasarkan hasil penelitian, penelitian terkait, dan teori pendukung maka didapatkan responden sebelum diberi kompres hangat paling tinggi berada pada tingkat nyeri sedang dan paling rendah berada pada nyeri ringan, sedangkan setelah pemberian kompres hangat didapatkan responden yang tertinggi berada pada tingkat nyeri ringan dan terendah berada pada nyeri sedang, hal ini membuktikan bahwa kompres hangat dapat mengatasi nyeri persalinan akibat terjadinya dilatasi serviks. Dengan adanya pemberian kompres hangat ini dapat memberikan rasa nyaman pada ibu karena dengan pemberia kompres hangat dapat 
meningkatkan aliran darah sehingga sirkulasi darah ke otot panggul menjadi homoestatis dan membuat ibu dapat mentoleransi nyeri selama persalinan akibat panas.Ketika kompres hangat diberikan ke daerah yang di kompres akan memberikan sinyal ke hipotalamus melalui sumsum tulang belakang dan pada saat reseptor peka terhadap panas akan mnyebabkan sistem effektor mengeluarkan keringat dan perifer. Hal ini akan mengubah ukuran pembuluh darah yang akan memperlancar oksiginesasi mencegah terjadinya kekakuan pada otot, membuat otot tubuh rileks, dan menurunkan nyeri yag di rasakan ibu bersalin.

\section{SIMPULAN}

Dari hasil penelitian yag dilakukan di BPM Rabiah Palembang dengan 10 responden, maka dapat diambil kesimpulan :

1. Distribusi frekuensi sebelum diberikannya kompres hangat sebaigian besar responden berada di tingkat nyeri sebesar 5 responden (50\%), sedangkan pada tinkgat nyeri ringan 1 responden (10\%).

2. Distribusi frekuensi sesudah diberikannya kompres hangat sebagian besar responden berada pada tingkat nyeri ringan 6 responden $(60 \%)$, sedangkan pada tingkat nyeri sedang sebesar 4 responden (40\%).

3. Berdasarkan hasil uji statistik wilcoxon signed rank test menunjukan nilai $p$ value $=0.003<\alpha$ $=0.05$, maka didapatkan perbedaan yang signifikan antara pengukuran tingkat nyeri sebelum dan sesudah dilakukan kompres hangat. Sehingga dapat disimpulkan bahwa tindakan kompres hangat yang dilakukan sesuai dengan aturan dapat menurunkan tingkat nyeri pada ibu bersalin fase aktif kala I.

\section{SARAN}

Bagi petugas kesehatan khususnya Bidandapat mengadakan upaya pengembangan pelayanan kesehatan khususnya pada ibu bersalin dan dapat menjadikan pemberian kompres hangat sebagai prosedur tetap dalam memberikan penanganan untuk mengatasi nyeri persalinan fase aktif kala I.

\section{DAFTAR PUSTAKA}

Asri, Dwi \& Clervo. 2012. Asuhan Persalinan Normal, Yokyakarta :Muha Medika.

Hidayat, Aziz. 2014. Metode Pnelitian Kebidanan dan Teknik Analisa Data. Jakarta :Salemba Medika.

H. Y. Kuncara. Alih bahasa oleh Chapman, Vicky (2006). Asuhan Kebidanan Kehamilan dan Kelahiran. Jakarta : ECG

Nopalia, Sherly. 2012. Pengaruh Kompres Hangat terhadap Suhu tubuh Pasien dengan Diare pada Blita di RSUP Dr. Mohammad Hoesin Palembang. Skripsi. Palembang

Nurlela. 2008. Pengaruh kompres hangat terhadap penurunan nyeri persalinan di RB. Arini S. Skiripsi. Kalimantan

Notoatmodjo, $\quad$ Soekijdo. 2010. Metodeologi Penelitian Kesehatan. Jakarta : Rineka Cipta.

Potter \& Perry. 2009. Skala pengukuran intensitas nyeri. Jakarta :ECG

Profil Dinas Kesehatan Kota Palembang. 2015. Data Cakupan Persalinan ditolong Tenaga Kesehatan Kota Palembang. Palembang

Profil Dinas Kesehatan Sumatera Selatan. 2014. Data Cakupan Persalinan ditolong Tenaga Kesehatan Sumatera Selatan. Sumatera Selatan

Profil Kesehatan Kementrian Kesehatan RI. 2014. Persalinan ditolong oleh tenaga kesehatan indonesia. Indonesia

Ratnasari, Dwi. 2015. Pengaruh Kompres Hangat terhadap Tingkat Nyeri Persalinan Kala I di BM Wilkaden Imogiri Bantul Yokyakarta. Skripsi. Yokyakarta 
Rohani, Saswita \& Marisah. 2011. Asuhan Kebidanan pada Masa persalinan. Jakarta : Salemba Medika,

Rukiah, Yeyeh Ai, Dkk. 2014. Asuhan Kebidanan 2 (Persalinan). Jakarta : Trans Info Media.

Sekolah Tinggi Ilmu Kesehatan Siti Khadijah Palembang. 2016. Panduan Karya Tulis Ilmiah Program Studi Diploma III Kebidanan. Stik Siti Khadijah Palembang. Palembang. Indonesia.

Sugyono, 2014. Metode Penelitian kualitatif dan kuantitatif, dan R\&D. Bandung: Alfabeta.

Suheimi. 2011. Persalinn tanpa nyeri. http://www.ksuemi.blogspot.com. Diakses 12 juni 2017.

Wahyuni. 2014. Pengaruh Kompres Hangat Terhadap Penurunan Skala Nyeri pada Ibu Bersalin di RB. Ananda Mojokerot. Skripsi.

Walyani, Sisi Elisabeth \& Purwoastuti. 2016. Asuhan Kebidanan Persalinan dan By baru lahir. Yokyakarta :Pustakabarupres.

Whalley, Jannet \& Penny Simkin. 2005. Kehamilan dan Persalinan. Jakarta : PT Bhuana Ilmu Populer.

WHO. 2012. Definisi Persalianan Normal Dunia tahun 2012//.com/0002//APN/2012.

Diakses pada tanggal 30 Mei 2017.

Wulandari. 2015. Pengaruh Pemberian Kompres Hnagat terhadap Intensitas Nyeri pada Ibu Bersalin Kala I Fase Aktif di RB. Mardi Rahayu. Skripsi. Semarang. 